\title{
Further Questioning Oral Communication Strategy Instruction From a Different Perspective: Is Implicit Learning Possible? \\ Meryem ÖZDEMIR-YILMAZER $^{\mathrm{a}^{*}}$, Esra ÖRSDEMIR ${ }^{\mathrm{b}}$ \\ ${ }^{a}$ Çukurova Üniversitesi, Yabancı Diller Yüksekokulu, Adana/Türkiye \\ ${ }^{\mathrm{b}}$ Çukurova Üniversitesi, Eğitim Fakültesi, Adana/Türkiye
}

\section{Article Info}

DOI: $10.14812 /$ cuefd.273785

Keywords:

Communication strategies,

Strategy training, Implicit strategy

training, English language learning.

\begin{abstract}
This study aims to investigate whether it is possible to learn communication strategies (CSs) implicitly through EFL teachers' modeling. In the context of EFL classrooms, nonnative EFL teachers are supposed to use CSs through which they are also supposed to model the CSs in their classes. Although the literature has an agreement on the fact that strategy training should be explicit, there is no empirical study found focusing on implicit strategy training. Therefore, this study aims to investigate to what extent EFL teachers' use of different communication strategies in the classroom predicts the communication strategies by students. The data of the study was collected by means of quantitative and qualitative data. As for quantitative data, participants were asked to fill into Oral Communication Strategy Inventory (OCSI). For the qualitative data, on the other hand, data was collected through structured interviews. The results indicated that EFL teachers do not model CSs because their strategies in use are rather teaching strategies like simplifying the language. When specifically analyzed, the only CSs explained by EFL teachers' use was message abandonment strategy. The implication of the study is that explicit strategy training should be provided for students' acquisition of these strategies, which is consistent with the literature.
\end{abstract}

\section{Sözlü Iletişim Startejileri Öğretimine Farklı Bir Bakış: Sözlü İletişim Starejilerini Örtük Olarak Öğrenmek Mümkün mü?}

Makale Bilgisi Öz

DOI: $10.14812 /$ cuefd.273785

Anahtar Kelimeler:

Iletişim stratejileri, strateji eğitimi, örtük strateji eğitimi, İngiliz dili eğitimi.
$\mathrm{Bu}$ çalışmanın amacı, öğrencilerin İngilizce öğretmenlerinin kullandığı stratejileri modelledikleri düşünülerek iletişim stratejilerinin örtük bir şekilde öğrenciler tarafından öğrenilip öğrenilmediğini araştırmaktır. İngilizce sınıfları bağlamında, İngilizceyi ikinci dil olarak öğreten öğreticilerin iletişim stratejilerini sınıfta kullandıkları düşünülmektedir. Alan yazında strateji öğretiminin açık bir şekilde yapılması yönünde bir görüş birliği olsa da, örtük strateji öğrenimi üzerine yapılmış bilimsel bir çalışmaya rastlanılmamıştır. Bu nedenle, bu çalışma, İngilizce öğretmenlerinin kullandıkları farklı iletişim stratejilerinin öğrencilerin kullandıkları iletişim stratejilerinin ne kadarını yordadığını araştırmayı amaçlamıştır. Çalışma için hem nitel hem de nicel veri toplama araçları kullanılmıştır. Nicel veri için katılımcıların "Sözlü İletişim Stratejileri Envanteri"ni doldurmaları istenmiştir. Diğer yandan nitel veri yapılandırılmış görüşme yoluyla toplanmıştır. Sonuçlar, öğretmenlerin sınıflarında iletişim stratejilerini kullanmadıklarını; kullandıkları stratejilerinin dili kolaylaştırma gibi öğretme stratejileri olduğunu ortaya koymuştur. Daha derine inildiğinde, öğrencilerin kullandığı stratejilerden öğretmen modellemesi kaynaklı olduğu tespit edilen tek stratejinin "mesajı bırakmama" stratejisi olduğu gözlemlenmiştir. Çalışmanın sonucunda -alan yazına paralel olarak- öğrencilere strateji eğitiminin açık olarak verilmesi gerektiği sonucuna varılmıştır.

Author: meryemzdemir@gmail.com 


\section{Introduction}

Individuals all around the world try to learn a second language for different purposes; however, the extent of the language attainment varies among learners. According to cognitive psychology, the reason of such a variance is individual learner's active participation in his/her learning process, using various mental strategies to sort out the system of language to be learned (Williams \& Burden, 1997). Taking the cognitive perspective in the account, the study of Selinker (1972) introduced the term "interlanguage" which indicates an internal system that language learner constructs over a period of time. Among the processes employed in the process of developing interlanguage, language learning strategies and second language (L2) communication strategies of which use differ individually are regarded as factors leading the individual differences among learners (Selinker, 1972).

In a broad sense, learning strategies are defined as specific actions, behaviors, steps or techniques to improve students' own progress in developing skills in a second or foreign language (Oxford, 1999). The place of learning strategies in second language acquisition is highlighted by O'Malley et. al. (1985) as they propose that while inherent developmental and experimental factors are primarily responsible for first language acquisition, learning strategies has the principal influence on learning a second language (p. 559).

Learning a second/foreign language clearly includes not only being competent grammatically and linguistically but also being competent communicatively as the primary function of language is enabling interaction between interlocutors. At this very point, there is differentiation in the literature between learning strategies and communication strategies (CSs). Following the distinction made by Selinker (1972) between L2 learning strategies and L2 communication strategies, Cohen et al. (1996) made a distinction between language learning strategies and language use strategies. That is, language learning strategies are defined as explicit goals of which aim is to help learners to improve their knowledge of the target language while language use strategies cover both performance and communicative strategies (Cohen et al., 1996). Communicative strategies, in this respect, are defined as conveying a message in the target language although having some gaps in the knowledge of target language (Cohen et al., 1996). The distinction and definition of CSs by Cohen et al. (1996) hold the psycholinguistic view in CSs literature as they focus more on production and comprehension in the target language.

The interactional view, on the other hand, emphasizes the negotiation of meaning between interlocutors. From the interactional viewpoint, Tarone (1980) differs CSs from learning strategies by suggesting that the motivation behind learning strategies is not a desire for conveying meaning but the desire for language learning (Tarone, 1980, p. 290). However, according to Tarone (1980), CSs subsume an intention to communicate in the target language, in the first place. From the interactionalist view of Tarone (1980), CSs are defined as "attempts to bridge the gap between the linguistic knowledge of second language learner and the linguistic knowledge of the target language interlocutor in real communication situation" (p. 288). Different perspectives held in CSs literature made the concept hard to conceptualize. Therefore, as Dörnyei (1997) indicates, there is no universally accepted definition of CSs resulting in several competing taxonomies of CSs. Although there are different taxonomies both on learning strategies and CSs, Bialystok (1990) remarks that these taxonomies differ in terminology, and there is a specific group of strategies that appear in the literature steadily (p.61).

Apart from the conceptual controversies in the definition of communication strategies, implementation of language learning strategies in the language classroom has been the focus of the researchers. The major discussion about the teachability of CSs exists between researchers advocating that strategies are part of general cognitive ability (Kellerman, 1991) and transferable from first language (L1) to the second one (L2) and the ones alleging that strategy training is effective in improving learners' performance (Dörnyei, 1995; Cohen et. al., 1996; Nakatani, 2005; Macaro, 2006).

Within the broad sense of language learning strategies, it was found out by O'Malley et. al. (1985) that EFL learners' cognitive strategy use is improved through strategy training. However, the results of 
O'Malley et. al.'s study (1985) also indicates that strategy training made no significant development in metacognitive strategies. This result is reasoned by the selected metacognitive strategy, namely, selective attention which is a planning strategy. As this kind of metacognitive strategy cannot be reflected upon by students through the learning process, metacognitive strategy training is found to be ineffective. In a similar vein, O'Malley and Chamot (1990) suggest that direct strategy training should be provided, which made students aware of the strategies they are being taught. Although these results are all related to the language learning strategies, Dörnyei (1995) implies that explicit strategy training is the case for CSs as well (p. 65).

Specifically for the CSs, Dörnyei (1995) investigated whether training of a specific strategy improves the learners' strategy use. The strategy training in this study focused on the solving learners' problems through production which did not require interaction. The results of the experimental study revealed that there was both quantitatively and qualitatively improvement among the participants in the experimental group regarding their strategy use. Cohen et al. (1998) also examined the effectiveness of strategy training on communication skills considering the metacognitive strategies such as preparation, self-monitoring, and self-evaluation. Their results also support that strategy training on communication skills helps to improvement in learners' oral performances. Furthermore, Nakatani (2010) explored the impact of oral communication strategy training on EFL learners. Different from the Dörnyei (1995) and Cohen et al. (1998), Nakatani (2010) included the negotiation of meaning strategies by adopting an interactionist view to CSs. Parallel to the previous two studies, the results illustrated that learners in the strategy training group improved their oral test scores compared to the control group.

The disputable notion of teachability of CSs seems to be clarified under the light of conducted studies. However, there is still no agreed Strategy Based Instruction. Plonsky (2011) reasons this absence by suggesting that the researchers cannot design studies of Strategy Based on convenience or intuition as there is a lack of theory.

Although there is a complexity in the theoretical background of the strategy training, there seems to be an agreement on what kind of strategies should be integrated into strategy training and how this training should be conducted on the side favoring teachability of CSs. Although results of the studies investigated the impact of the strategy training on EFL/EFL learners support the explicit and formal training of CSs, there is no research found, as far as reviewed, focusing on implicit CSs learning through EFL teachers' modeling these strategies in the classroom. EFL teachers whose native language is not English are assumed to use CSs in their interaction with students. Thus, it is inevitable for these teachers to model these strategies to EFL/EFL learners in an implicit way. Therefore, this study aims to investigate to what extent CSs used by teachers are parallel to the ones used by students. If so, it is further aimed to explore whether the CSs used by teachers predict the CSs used by students in an attempt to reveal the effectiveness/ineffectiveness of implicit strategy training in the classroom. Lastly, it is planned to identify the CSs used both by EFL students and EFL teachers. Therefore, the research questions directing the present study are:

1- What are the communication strategies that are commonly used by EFL teachers?

2- What are the communication strategies that are commonly used by EFL students?

3- To what extent do communication strategies used by EFL teachers predict the communication strategies used by EFL students?

\section{Method}

\section{Participants and Context}

$19 \mathrm{EFL}$ teachers and one student of each EFL teacher (19 EFL students) who were selected through random sampling participated in the present study. Although the experience of EFL teachers varies among teachers, all EFL students participated in the study were beginner level students attending 
preparatory classes at Foreign Language School at different universities in Turkey. These universities were Çukurova University, Mustafa Kemal University, Sütçü Imam University and Adıyaman University. The curriculum differs among these schools; however, as it is investigated, there is no specific course focusing on oral communication/speaking skills. Communication skills or speaking skills are taught as an integrated part of the main course. The data was collected through the end of fall semester of the 20132014 academic year when the students have been already learning English as a second language since September. Out of 19 EFL teachers, 6 of them voluntarily participated in the interview conducted in the study.

\section{Instrument}

Since both quantitative and qualitative data were collected, this study has a mixed research design. Quantitative data was collected through Oral Communication Strategy Inventory (OCSI) developed by Nakatani (2006). The scale was adapted in Turkish by Kavasoğlu (2013). The inventory has five factors which are labeled as "negotiation for meaning strategies, message abandonment strategies, planning/organizing strategies, affective strategies, compensatory strategies" (Nakatani, 20006; Kavasoğlu, 2013). The Cronbach alpha coefficiency of the adapted scale was found to be 0,79 ; the Cronbach alpha coefficiency values for subscales of the adapted version are 0,81 for negotiation for meaning strategies; 0,69 for message abandonment strategies; 0,67 for planning/organizing strategies; 0,63 for affective strategies and 0,63 for compensatory strategies (Kavasoğlu, 2013).

In addition to quantitative data, qualitative data was collected through structured interview. The interview including eight questions sent to EFL teachers who voluntarily accepted to participate in interviews. The question of the interview was prepared by the researcher by taking both the reviewed literature and the preliminary results of the quantitative data analysis into account. Via e-mail, EFL teachers sent back the interview questions. The interview is included in the design of this study to get a deeper insight into the CSs modeled by the EFL teachers in the classroom. Moreover, the interview also tries to delve into the teachers' attitudes towards CSs training in the classroom and whether teachers underline CSs in their classes or not. Through the triangulation of both quantitative and qualitative data, it is intended to access more reliable and valid result focusing on implicit CSs training through EFL teachers' modeling.

\section{Data Analysis}

The qualitative data were analyzed through SPSS 15 for Windows. In an attempt to find out the most frequently and least frequently used CSs both by EFL teachers and students, descriptive analysis was conducted. Furthermore, correlation analysis was employed so as to sort out the existence/absence of a correlation between CSs used by EFL teachers and EFL students. Finally, regression analysis which was used for the investigation of the prediction value of CSs used by EFL teachers explaining CSs used by EFL students was conducted. Through simple linear regression analysis, it was tried to get an idea whether CSs used by EFL teacher train EFL students regarding their use of CSs. Besides the analysis of quantitative data, qualitative data were analyzed through content analysis. In content analysis, the keywords in the answers of participants were elicited; then, they were grouped under the strategy names according to CSs' names presented in Dörneyi's study (1997) in which he examined all the CSs in literature. After all, these CSs were mainly grouped under strategy labels as stated in the factor structure of OCSI to have consistency with quantitative data.

\section{Result and Discussion}

The results of the study will be presented in this part following the order of the research questions. The results will be discussed under the light of reviewed literature. 


\section{What are the communication strategies that are commonly used by EFL teachers?}

To elicit the communication strategies that are commonly used by EFL teachers, the descriptive statistics were conducted on the quantitative data. To this end, the mean ranks of the factors included in the OCSI were measured of which results were shown in Table 1 below.

Table 1.

Common communication strategies used by EFL teachers

\begin{tabular}{lccccc}
\hline Strategy Categories & N & Minimum & Maximum & Mean & S \\
\hline Negotiation for Meaning & 19 & 3,57 & 5,00 & 4,5 &, 416 \\
Affective & 19 & 3,00 & 5,00 & 4,4 &, 604 \\
Compensatory & 19 & 3,25 & 5,00 & 4,4 &, 481 \\
Planning/Organizing & 19 & 1,20 & 4,60 & 2,7 &, 828 \\
Message Abandonment & 19 & 1,00 & 3,25 & 1,8 &, 724 \\
\hline
\end{tabular}

As it can be seen clearly in Table 1 , EFL teachers mostly use negotiation for meaning strategies $(M=4,5 ; S=416)$, followed by compensatory strategies $(M=4,4 ; S=481)$, affective strategies $(M=4,4$; $S=, 604)$, planning/organizing strategies $(M=2,7 ; S=, 828)$, and message abandonment strategies $(M=1,8$; $S=, 724)$, relatively. This result is in line with Kavasoğlu's (2011) study in which she measured the strategies used by English Language Teaching (ELT) students. This study concluded that ELT students use negotiation for meaning strategies and compensatory strategies more frequently though their least frequently used strategies are abandonment strategies (Kavasoğlu, 2011). The use of message abandonment strategies least frequently may be a result of the proficiency level of teachers in the present study. As they are advanced learners of English, it is meaningful for them not to abandon the message while communicating in English.

Apart from the EFL teachers' CSs that they use in communication, the CSs that they use in class are also elicited through content analysis of EFL teachers' answers in the structured interview. According to the results of the content analysis, EFL teachers were observed to use compensation strategies more frequently (seen ten times), and message negotiation for meaning strategies (seen six times). The qualitative results are parallel to the quantitative results as both of them indicates that EFL teachers use negotiation for meaning strategies and compensation strategies more frequently. However, as it was clearly understood from the answers of EFL teachers, the strategies they use in the classroom is far from the definition of communication strategies which was stated as "getting a message across in the target language despite gaps in target language knowledge" (Cohen et. al., 1996, p. 4) as the gaps in the target language knowledge of EFL teachers is supposed to be less. Therefore, the EFL teachers' use of CSs in classroom is a teaching strategy rather than communication strategy which is explicit in the excerpt of one of the teachers:

"I speak according to the level of the students; I get a help of the exemplification when I think that I do not get understood. Moreover, I try to make them (students) understand by using different words; I make use of the context."

It is clear in this excerpt that the teacher uses compensation strategies to make the language simpler for the students' level, and negotiate the meaning till the students understand the teacher's message. Therefore, it may be concluded that the use communication strategies by EFL teachers in the classroom have a different goal like achieving students' understanding unlike the communication strategies used in the real communicative setting. 


\section{What are the communication strategies that are commonly used by EFL students?}

Common communication strategies used by EFL students were also elicited through descriptive analysis conducted on quantitative data obtained from them. The results of the descriptive analysis were presented in Table 2, below.

Table 2.

Common communication strategies used by EFL students

\begin{tabular}{lccccc}
\hline Strategy Categories & $\mathrm{N}$ & Minimum & Maximum & Mean & $\mathrm{S}$ \\
\hline Compensatory & 19 & 3,25 & 5,00 & 4,2 &, 480 \\
Negotiation for Meaning & 19 & 2,86 & 5,00 & 4,0 &, 567 \\
Affective & 19 & 2,33 & 5,00 & 3,8 &, 740 \\
Planning/Organizing & 19 & 2,40 & 4,80 & 3,7 &, 571 \\
Message Abandonment & 19 & 1,00 & 5,00 & 2,4 & 1,02 \\
\hline
\end{tabular}

The results of the descriptive statistics suggest that EFL students frequently use compensatory strategies $(M=4,2 ; S=, 480)$ followed by negotiation for meaning strategies $(M=4,0 ; S=, 567)$, affective strategies $(M=3,8 ; S=, 740)$, planning/organizing strategies $(M=3,7 ; S=, 571)$, and message abandonment strategies $(M=2,4 ; S=1,02)$, relatively. Similar to their teachers, EFL students are found to use message abandonment strategies least frequently. However, this result obtained from quantitative data is challenged by content analysis of qualitative data, as EFL teachers reported that their students most frequently use message abandonment strategies (seen seven times) in the classroom along with the compensation strategies (seen six times) and planning strategies (seen two times). This result is intriguing regarding this inconsistency between the results of quantitative and qualitative data analysis. However, this result may be interpreted in a way that EFL teachers are aware of the fact that their students mostly abandon the message in communication, and they explicitly train them not to do it in their courses. As a result of such an explicit training of message abandonment strategies, EFL students have learnt not to use it during communication. More detailed results are supposed to be received on this point through regression analysis along with the content analysis that was employed to answer the following research question.

To what extent do communication strategies used by EFL teachers predict the communication strategies used by EFL students?

Simple linear regression analysis was conducted so as to investigate the prediction value of CSs used by EFL teachers for their students' use of CSs. In an attempt to do that, CSs used by EFL teachers were selected as a dependent variable whereas EFL students were chosen as an independent variable. The regression analysis conducted on the sum values of OCSI scale was presented in Table 3 below.

Table 3.

The results of regression analysis

\begin{tabular}{llllll}
\hline & $\mathbf{F}$ & $\mathbf{t}$ & $\mathbf{p}$ & $\mathbf{R}$ & $\mathbf{R}^{2}$ \\
\hline $\begin{array}{l}\text { Prediction value EFL } \\
\text { teachers use of CSs on }\end{array}$ &, 554 &,- 744 &, 467 &, 178 &, 032 \\
EFL students' use of CSs & & & & & \\
\hline
\end{tabular}


The regression analysis indicated that EFL teachers' use of CSs does not significantly predict the CSs which are used by their students $(p>0,05)$. The simple linear regression analysis was also conducted for five different CSs that are sub-factors of OCSI. The results were presented in Table 4.

Table 4.

The results of the regression analysis for five different CSS

\begin{tabular}{lccccc}
\hline & $\mathrm{F}$ & $\mathrm{t}$ & $\mathrm{p}$ & $\mathrm{R}$ & $\mathrm{R}^{2}$ \\
\hline Message Abandonment & 4,93 & 2,22 &, 040 &, 474 &, 225 \\
Planning/Organizing & 1,33 & 1,15 &, 265 &, 269 &, 072 \\
Negotiation for meaning &, 542 &,- 736 &, 472 &, 176 &, 031 \\
Affective &, 488 &,- 699 &, 494 &, 167 &, 028 \\
Compensatory &, 233 &, 482 &, 636 &, 014 \\
\hline
\end{tabular}

According to Table 6, EFL teachers' use of negotiation for meaning strategy, message planning/organizing strategy, affective strategy and compensatory strategy does not significantly predict their students' use of these strategies $(p>0,05)$. However, it was found out that EFL teachers' use of message abandonment strategy significantly predicts their students' use of this strategy $(p<0,05)$. Message abandonment strategies used by EFL teachers explain \%22 of the total variance of message abandonment strategies used by their students $\left(R^{2}=, 225\right)$. Although explained variance is not too high, it is interesting to find out that only message abandonment strategy is discovered to be predictable by EFL teachers' use of this strategy among all other strategies.

This result clearly explains the inconsistency found between quantitative and qualitative data analysis regarding the strategy used by EFL students. As indicated before, while EFL teachers remarked that their students used message abandonment strategies most frequently, EFL students report themselves to use this strategy less frequently. These results together may be commented as EFL teachers explicitly focus on the message abandonment strategy rather than just being a model for this strategy. Teachers' being aware of their students' use of message abandonment strategy may inevitably make them emphasize not to give up while communication. This result can also be supported by the qualitative data analysis, as the EFL teachers report that they explicitly warn their students not to make code switching or to give up to negotiate the meaning. The excerpt below is taken from the answers of one of the teachers:

\section{"...I say them (to students) never turn back to Turkish."}

At the beginning of the study, it was hypothesized that non-native EFL teachers are also learners of a second language. Hence, they are assumed to use communication strategies while communicating in English. Considering this assumption, it was inferred that EFL teachers might model CSs in their classes to their students. Although the literature agreed on the fact that strategy training should be explicit, there is no empirical study found on the implicit impact of strategy training in EFL classes as far as the literature review. The results of the present study are in line with the studies in the literature though it empirically sounds that CSs cannot be learnt implicitly. The reason for such a result is that EFL teachers were found to use some CSs in their classes; however, this strategy labeled as CSs in content analysis does not indicate any strategy employed at a time when a problem is encountered in communication; rather they were teaching strategies by which teachers simplify the language according to the level of their students. Therefore, it may not be possible to mention a kind of modeling regarding CSs in EFL classes. The quantitative data analysis showed a parallel result indicating that there is no correlation between CSs used by EFL teachers and their students. One exception of this result was EFL teachers' use 
of message abandonment strategy was found to be positively correlated with their students' use of this strategy. Further, it was revealed that EFL teachers use of message abandonment strategy predicts their students' use of this strategy. This result may stem from the fact that EFL teachers explicitly focus on this strategy. Focussing on, in this sense, is different from modeling. That is, EFL teachers might encourage students to convey the message till the intended message ends. This encouragement was obvious in teachers' interviews.

Although the aim of the present study was not imply anything about the impact of explicit strategy training on EFL students, the overall results of the study indicate that CSs strategies can be taught if they are explicitly emphasized by the teachers (as in the case of message abandonment strategies). This result supports the results of the previous studies which found out that CSs can be teachable if metacognitive awareness is raised (Dörnyei, 1995, Cohen et al., 1998; Nakatani, 2010). Moreover, as in the case of overall CSs, it may not be possible to achieve strategy training in the classroom, as the primary goal is conveying the message in the classroom (Canale \& Swain, 1980; Bialystok, 1981). Especially, for the beginner level of students, like the ones in this study, the teachers essentially cater for students' understanding of language rather than to be a model for CSs. One of the teachers reports that fact clearly:

"As my students know little about English, I do not think myself as a good model for strategy."

\section{Conclusion}

The aim of this study is to investigate the possibility of implicit learning of CSs through EFL teachers' modeling. Therefore, CSs used by both EFL teachers and EFL students were identified in the first place. Secondly, the correlation between CSs used by EFL teachers and CSs used by EFL students was investigated. Further, the causality between EFL teachers' use of CSs and their students' use of CSs was analyzed.

The results of the study imply that it is not possible to teach CSs implicitly through modeling as EFL teachers' primary goal was not modeling the use of language but to make students understand the language. However, the explicit focus on CSs seems to be fruitful, as in the message abandonment strategy in this study. It was found out that EFL teachers encourage their students not to abandon the message which results in an impact of EFL teachers' use of this strategy on their students' usage, as well.

The results of this study are consistent with studies which investigated the teachability of CS. It is agreed that once metacognitive awareness is raised; it is possible to teach CSs. However, this study may be significant as it empirically sounds that implicit strategy learning in the classroom does not work specifically for beginner level EFL students for numerous reason one of which EFL teachers do not model CSs, but they try to make their students understand the intended message. However, when the strategy is presented explicitly, it may be possible for students to internalize the CSs as in the case of message abandonment strategy in this study.

\section{Limitation and Further Research}

This study is limited from various aspects. First of all, it was not possible to access more participants for both qualitative and the quantitative part of the study. With the participation of more EFL teachers and students, the results might have been sounder. Additionally, it was not possible to access EFL students for the interviews. Thus, the CSs used in classroom lacks the perspective of EFL students. Secondly, the data obtained in the study might have been stronger if classroom observation had been implemented into the study. Moreover, the results of the study might have been more valid if it was possible to employ an experimental research design. Explicit and implicit strategy training may have been compared to an experimental and control group. Taking these limitations into consideration, a further research may be conducted to obtain deeper insight into the teachability of CSs in either explicit or implicit way. 


\section{References}

Bialystok, E. (1981). The role of conscious strategies in second language proficiency. Modern Language Journal, 65, 24-35.

Canale, M. \& Swain, M. (1980). Theoretical bases of communicative approaches to second language teaching and testing. Applied Linguistics, 1, 1-47.

Cohen, A. D., Weaver, S. J., \& Li, T.-Y. (1996). The impact of strategies-based instruction on speaking a foreign language (Research Report). Minneapolis, MN: University of Minnesota, National Language Resource Center.

Dörnyei, Z. (1995). On the teachability of communication strategies. TESOL Quarterly, 29, (1), 55-85.

Dörnyei, Z., \& Scott, M. L. (1997). Communication strategies in a second language: Definitions and taxonomies. Language Learning, 47, (1), 173-210.

Gass, S. M., \& Selinker, L. (2008). Second Language Acquisition. New York: Routledge.

Kavasoğlu, M. (2011). Oral communication strategies used by Turkish students learning English as a foreign language: the development of "oral communication strategy inventory." (Unpublished masters thesis). Mersin University, Mersin.

Macaro, E. (2006). Strategies for language learning and for language use: revising the theoretical framework. The Modern Language Journal, 90, 320-337.

Mitchell, R., Myles, F., \& Mardsen, E. (2013). Second Language Learning Theories. New York: Routledge.

Nakatani, Y. (2005). The effects of awareness-raising training on communication strategy use. The Modern Language Journal, 89, (1), 76-91.

Nakatani, Y. (2010). Identifying strategies that facilitate EFL learners' oral communication: A classroom study using multiple data collection procedures. The Modern Language Journal, 94, (1), 116-136

O’Malley, J. M., Chamot, A. U., Stewner-Manzaneres, G., Russo, R. P., \& Küpper, L. (1985). Learning Strayegy Applications with students of English as a second language. TESOL Quarterly, 19, (3), 557-584.

Oxford, R. L. (1989). Use of language learning strategies: A synthesis of studies with implications for strategy training. System, 17(2), 235-247.

Plonsky, L. (2011). The effectiveness of second language strategy instruction: A meta-analysis. Language Learning, 61(4), 993-1038.

Selinker, L.(1972). Interlanguage. International Review of Applied Linguistics, 10(3), 209-230

Tarone, E. (1981). Some thoughts on the notion of communication strategy. TESOL Quarterly,15, (3), 285-295.

Williams, M., \& Burden, R. L. (1997). Psychology of Language Teachers. Cambridge: Cambridge University Press.

Yaman, Ş., Kavasoğlu, M. (2013). The adaptation study of oral communication strategy inventory into Turkish. International Journal of Human Sciences, 10 (2), 400-419. 